\title{
Redactioneel
}

\section{Een nieuwe naam, hetzelfde geluid}

De letselschadebranche kenmerkt zich door een grote diversiteit aan disciplines. Juristen, artsen, arbeidsdeskundigen, rekendeskundigen, ergotherapeuten, (neuro)psychologen, herstelcoaches, casemanagers en ga zo maar door, werken in veel letselschadezaken nauw samen. Vooral bij blijvend letsel of bij om een andere reden complexe dossiers. Dat multidisciplinaire karakter werd tot 2014 niet in de vakliteratuur weerspiegeld. Die werd vrijwel volledig gedomineerd door juristen. Daarmee bleven nieuwe ontwikkelingen en inzichten op nietjuridische vakgebieden vrijwel onbelicht.

Die lacune leidde in 2014 tot oprichting van $T L P$, een tijdschrift dat zich profileerde als een multidisciplinair vakblad. In 2018 verscheen de laatste aflevering van dit tijdschrift. De redactie kondigde aan te hopen onder een andere vlag te kunnen doorgaan. Die hoop is uitgekomen, met hulp van Boom juridisch.

Voor u ligt het eerste nummer van Afmikkeling Personenschade $(A P)$. De redactie van dit tijdschrift is dezelfde als de redactie van $T L P$. $A P$ wil, net als destijds $T L P$, een platform bieden aan niet-juristen om relevante inzichten buiten het aansprakelijkheidsrecht te signaleren. Dit kan in sommige gevallen een anzet geven tot verdere ontwikkeling van hun vakgebied. Daarnaast krijgen juristen de gelegenheid om onderwerpen aan de orde te stellen op het gebied van aansprakelijkheid, causaal verband en schadebegroting en zal in ieder nummer een overzicht worden opgenomen van relevante jurisprudentie in de daaraan voorafgaande periode. Op die manier wordt het gebied van de afwikkeling van personenschade met een multidisciplinaire blik bezien. Die multidisciplinaire blik op letselschade is nuttig en nodig. Niet alleen als afspiegeling van de praktijk, waar samenwerking tussen deskundigen van diverse pluimage aan de orde van de dag is, maar ook omdat vakinhoudelijke kruisbestuivingbestuivingen inspirerend kunnen zijn.
De redactie is enthousiast over de formule van $A P$. We rekenen erop dat dit enthousiasme zich vertaalt in een blad dat relevant is voor de letselschadepraktijk en zo zijn naam waar kan maken. 